\title{
Uppermost Berriasian macro- and microfossil assemblages from the Ticha Formation of the Eastern Fore-Balkan Mts (Bulgaria)
}

\author{
Silviya Petrova \\ Geological Institute, Bulgarian Academy of Sciences, Acad. G. Bonchev Str., Bl. 24, 1113 Sofia, Bulgaria; \\ e-mail: silviya_p@geology.bas.bg
}

(Accepted in revised form: November, 2020)

\begin{abstract}
Late Berriasian macro- and microfossil assemblages from the Ticha Formation (Eastern ForeBalkan Mts, Bulgaria) were studied. Eight ammonite taxa, including coiled and straight forms, were described. In addition, 23 calpionellid, 12 calcareous dinocyst and 4 foraminiferal taxa were identified. The “Thurmanniceras" otopeta ammonite Subzone of the Tirnovella alpillensis Zone, the calpionellid Oblonga Subzone of the Calpionellopsis Zone and the Stomiosphaera wanneri calcareous dinocyst Zone were indicated. The advent of Bochianites neocomiensis, the late occurrence of Bochianites (?) ambiguus and the earliest appearance of Phylloceras (Hypophylloceras) tethys tethys was documented in the Eastern Fore-Balkan Mts area. The calpionellid-spicule microfacies was also recognized. The fossil data allow a correlation with similar coeval localities of the European Tethyan Realm. Pelagic macro- and microfossils and the microfacies are indicative of deeper-water basin depositional settings.
\end{abstract}

Petrova, S. 2020. Uppermost Berriasian macro- and microfossil assemblages from the Ticha Formation of the Eastern Fore-Balkan Mts (Bulgaria). Geologica Balcanica 49 (3), 19-37.

Keywords: ammonites, microfossils, Bochianites, uppermost Berriasian, Eastern Fore-Balkan Mts, Bulgaria.

\section{INTRODUCTION}

The first detailed studies of the Lower Cretaceous sub-flysch sediments and ammonite faunas of the Ticha Formation in the Eastern Fore-Balkan Mts area were made by Nikolov $(1960,1962)$ and Atanassoff (1961). The ammonite data from these papers defined a late Berriasian-Valanginian age of the formation, although the Berriasian Stage was perceived as a part of the Valanginian at that time. Atanassoff (1961) also published a few calpionellid species, which have been attributed to the Berriasian. Soon after, Mihailova-Yovcheva and Trifonova (1967) reported a Late Jurassic-Early Cretaceous age for the Ticha Formation based on foraminifera and calpionellids from a borehole section located near the fossil site of the present study. Later on, Sapunov et al. (1986) investigated the borehole sections penetrating the Ticha Formation in the Provadiya region (NE of the area studied herein). The ammonite, dinoflagellate and calpionellid data of the lat- ter paper defined a total extent of these strata from the Oxfordian to the lower Berriasian. Tithonian ammonite zones, from the Hybonoticeras hybonotum to the Himalayites (Micracanthoceras) microcanthus subzone of the Paraulacosphinctes transitorius Zone, were indicated. The Chitinoidella, Crassicollaria and Calpionella calpionellid zones (with the C. alpina Subzone), were also recognized. More recently, Ivanova et al. (2002) restudied some of the borehole sections of Sapunov et al. (1986) and correlated the range of three microfossil groups: calpionellids, calcareous and non-calcareous dinoflagellate cysts. These authors confirmed the previously obtained results and further expanded the microfossil evidence up to the Valanginian. Calpionellid zones (from the Chitinoidella Zone to the Tintinnopsella Zone), calcareous dinocyst zones (from the Carpistomiosphaera tithonica Zone to the Stomiosphaera echinata Zone), as well as dinoflagellate cysts zones (from the Biorbifera johnewingii Zone to the Spiniferites spp. Zone), were identified. 
As a result, the total chronostratigraphic extent of the Ticha Formation has been extended from the late Callovian to the late Valanginian (Ivanova et al., 2002). Petrova and Metodiev (2012) studied the calpionellid successions of the Ticha Formation from outcrops in the area between the rivers of Luda Kamchiya and Armera. Three calpionellid zones and their composing subzones (from the Calpionellopsis Zone to the Tintinnopsella Zone), were indicated and allowed to assign these strata to the upper Berriasian and the Valanginian.

This paper is a renewed effort to study the fossil components of the Ticha Formation from the Luda Kamchiya-Armera area. It is focused on a specific locality, with a narrow range of the uppermost Berriasian, in which abundant representatives of the ammonite genus Bochianites, a few other ammonite taxa and various microfossils (calpionellids, calcareous dinocysts and foraminifera) were recorded. The microfacies of the fossil-surrounding rocks was also determined, and thus, in addition to the direct correlation between the different fossil groups, an interpretation of the depositional environment was made.

\section{GEOLOGICAL SETTING}

The Luda Kamchiya-Armera area (Fig. 1a) includes the eastern part of the Predzhan anticline (Vangelov and Sinnyovsky, 2007). This regional structure of the Balkan Zone is composed of various Upper Cretaceous-Paleogene rocks, lying unconformably upon Lower Cretaceous sedimentary successions (Fig. 1b-c). The Lower Cretaceous strata correspond to the Ticha and Kamchiya for-

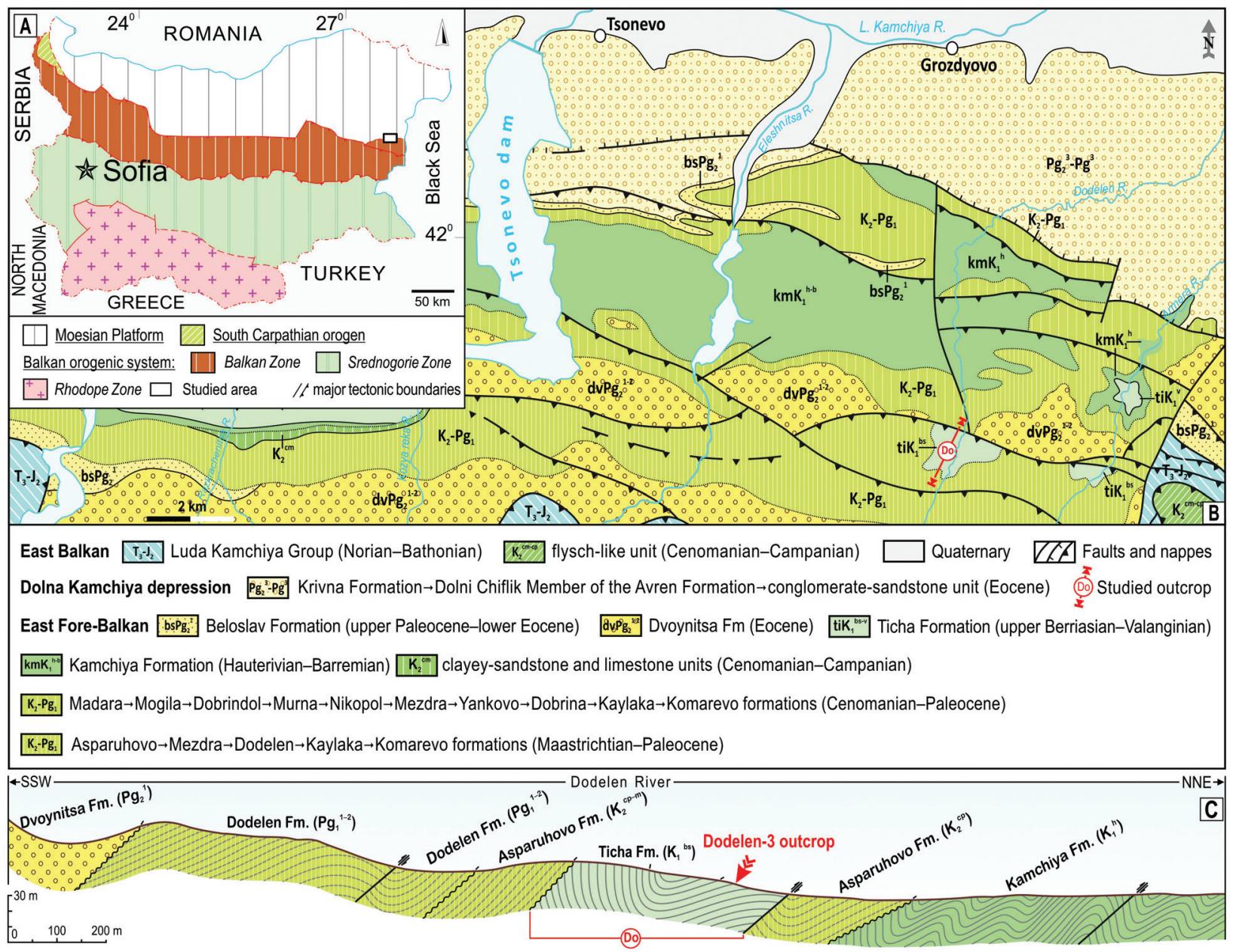

Fig. 1. a) Simplified tectonic sketch showing the position of the studied area within the framework of the Balkan orogenic system and its foreland in Bulgaria (after Dabovski and Zagorchev, 2009; modified); b) Schematic geological map of the East Fore-Balkan between the Luda Kamchiya and Armera rivers (after Vangelov and Sinnyovsky, 2007; modified), containing the Dodelen profile; c) Profile along the Dodelen River Valley with position of the Dodelen-3 outcrop. 
mations. The Ticha Formation was introduced by Sapunov (1976). It crops out in several isolated narrow strips with W-E direction, south and southeast from the Tsonevo Dam (Fig. 1b). The formation is represented by an irregular alternation of gray marlstones, clayey and micritic limestones and rare layers of calcareous siltstones and sandstones. Nikolov et al. (1991) noted that, in the scope of the Predzhan anticline, the Ticha Formation is characterized by appreciable presence of clay-clastic rocks. Its thickness varies from 25-30 m to 100-200 m. According to Ivanova et al. (2002) the total chronostratigraphic extent is from the upper Callovian to the upper Valanginian. The formation is covered, with either a rapid lithological transition or angular unconformity, by the sediments of the Kamchiya Formation (along the valley of the Razkrachenitsa River), or by the sediments of the Upper Cretaceous (along the valleys of the Kozya Reka, Dodelen and Armera rivers), correspondingly (see Fig. $1 b, c$ ). Along the valley of the Dodelen River, the Ticha Formation forms a locally developed W-E oriented synform, which is tectonically limited from north and south. This fold is composed of a few meters-thick alternation of light gray thin-bedded clayey limestones, micritic limestones and marlstones. A 1-m thick fossiliferous interval, called the Dodelen-3 outcrop, was found and studied. It is located in the Sherba Hunting Farm (42 $\left.57^{\prime} 16.28^{\prime \prime} \mathrm{N} ; 2^{\circ} 31^{\prime} 7.28^{\prime \prime} \mathrm{E}\right)$ and corresponds to clayey and micritic limestones with rare marlstone interbeds (see Fig. $2 a-d$ ). This site contains six levels of ammonite faunas, in which coiled and straight forms are very common at the base and rapidly decrease to single specimens at the top.

\section{MATERIAL AND METHODS}

A total of 43 ammonite specimens were studied. They are preserved predominantly as deformed and
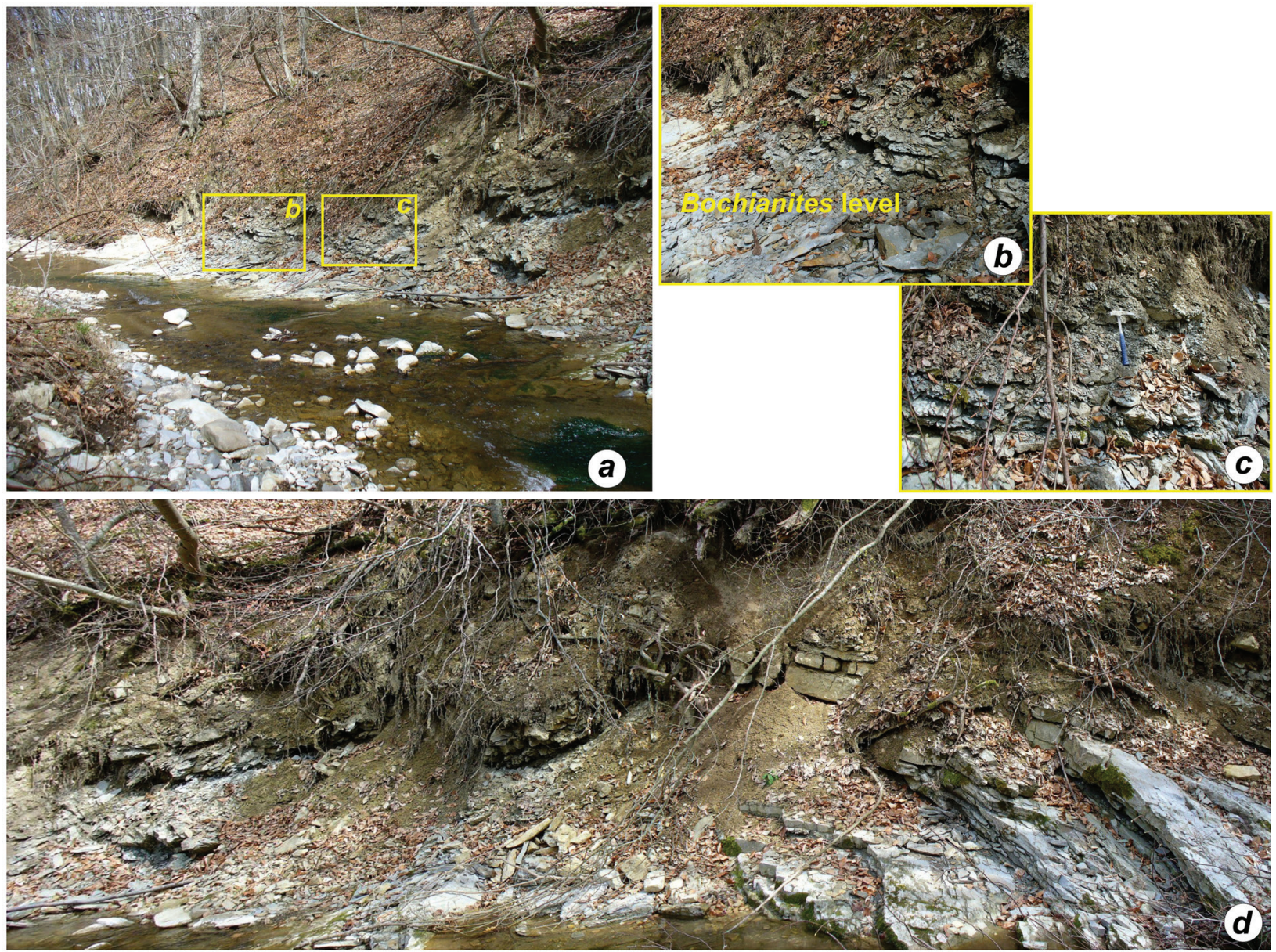

Fig. 2. Field views of the Ticha Formation from the Dodelen-3 outcrop: $a$ ) Alternation of light grey thin-bedded clayey limestones, light grey thin-bedded micritic limestones and rare layers of light grey marlstones (lower part of the outcrop); $b, c$ ) Detailed views of the Ticha Fm. (see Fig. 2a); d) Upper part of the outcrop. 
fragmented internal molds. This state of preservation is due to sediment compression and considerable tectonic deformation. Ammonites are figured without additional treatment and mostly in natural size. One sample (thin-section Do 8) was taken for microfossil and microfacies studies from the lowermost ammonite-rich level (see Fig. 3). The identification of calpionellids, calcareous dinocysts and benthic foraminifera, as well as the accompanying allochems and matrix, was performed on a Jenaval transmitting light-microscope. The following literature was used in the taxonomic definitions: 1) calpionellids: Doben (1963); Remane (1963, 1965); Borza (1969); Pop (1994a, b, 1997a); and Lakova and Petrova (2013); 2) calcareous dinocysts: Borza (1969); Lakova et al. (1999); Reháková (2000); Ivanova and Kietzmann (2017); Petrova et al. (2019); and 3) benthic foraminifera: Bucur (1997); Ivanova and Kołodziej (2010); Petrova et al. (2012); Ivanova et al. (2015); Kowal-Kasprzyk (2016); and Bakhmutov et al. (2018). Microfacies was determined based on the textural classification of Dunham (1962) and the predominant microfossil content in accordance to the microfacies of Lakova et al. (2007).

The examined materials are housed in the Department of Paleontology, Stratigraphy and Sedimentology of the Geological Institute "Str. Dimitrov" (Sofia, Bulgaria).

\section{RESULTS}

\section{Microfossil data}

The microfossil content recorded in the Dodelen-3 outcrop is characterized by rich calpionellid and calcareous dinocyst associations and less common small benthic foraminifera (Figs 3-6). In total, 23 calpionellid, 12 calcareous dinocyst and four foraminiferal taxa were identified.

The calpionellid community consists of abundant representatives of Calpionellopsis oblonga (Cadisch, 1932), Calpionellopsis sp. A (sensu Lakova and Petrova, 2013), Calpionella alpina Lorenz,

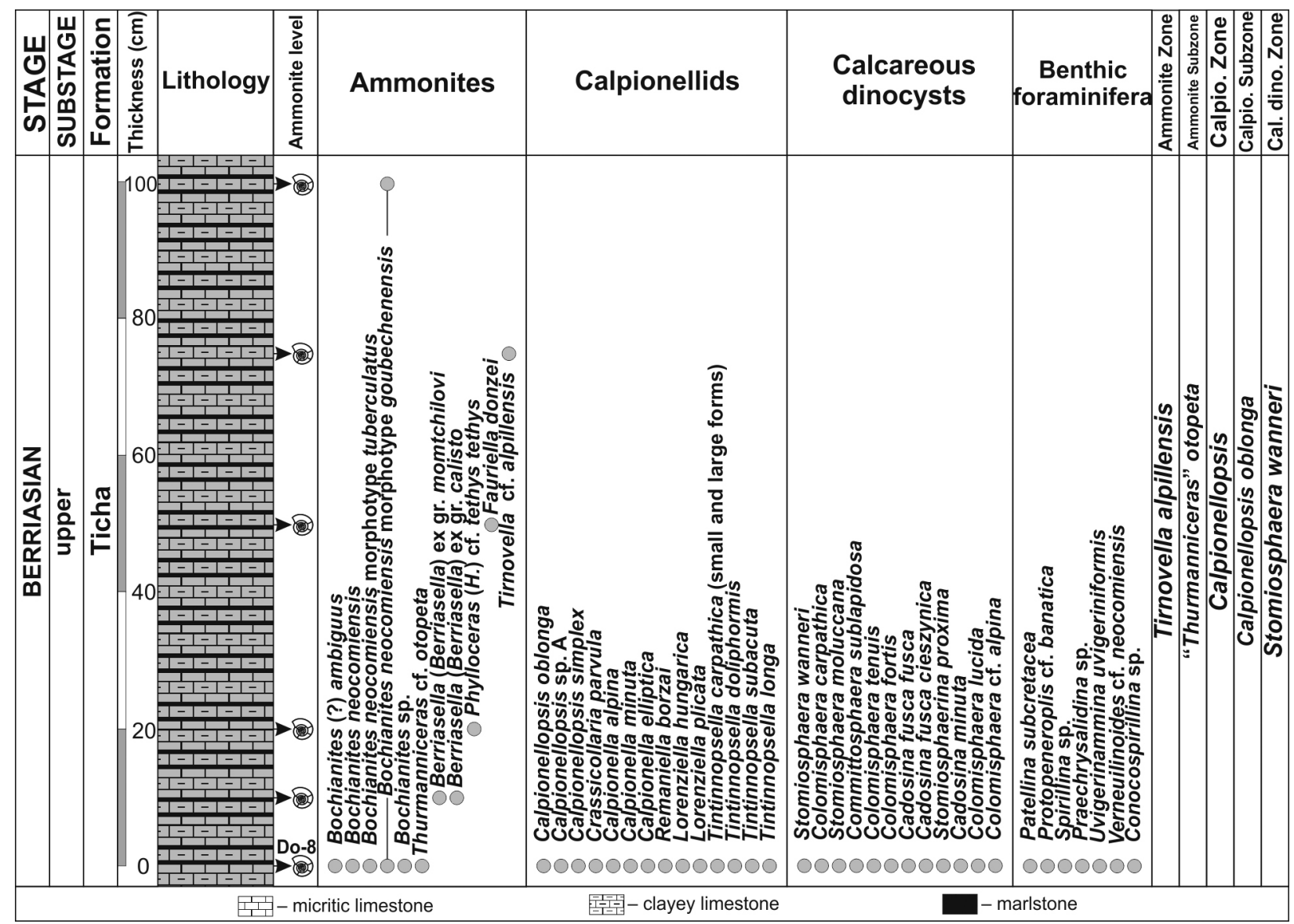

Fig. 3. Dodelen-3 outcrop: litho- and biostratigraphy, range-chart of the ammonite, calpionellid, calcareous dinocyst and foraminifer species. The microfossils were found in sample Do-3, taken from the first ammonite level. 


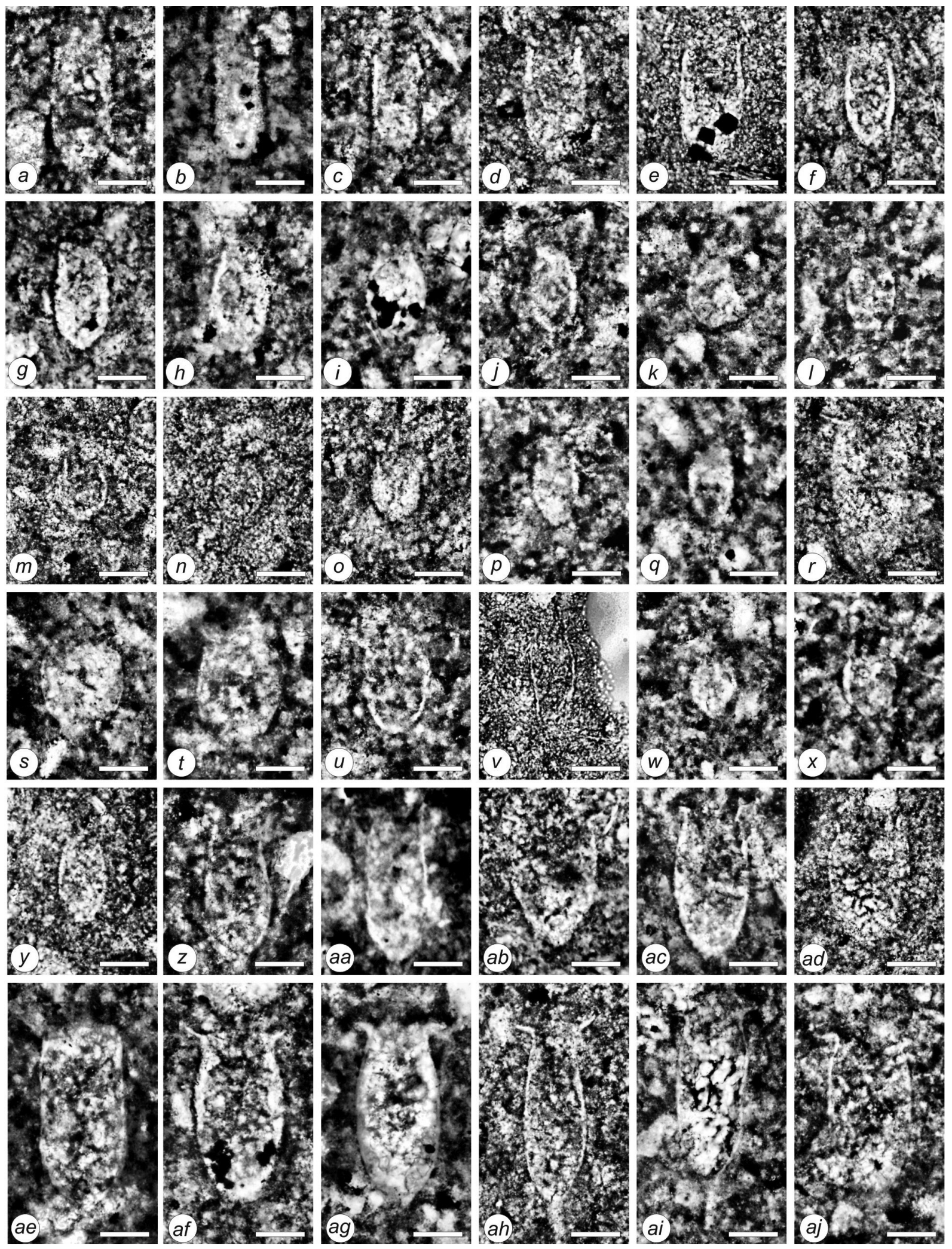

Fig. 4. Calpionellids of the Dodelen-3 outcrop (Ticha Formation, sample Do-8, Calpionellopsis oblonga Zone, upper Berriasian): $a-c$ ) Calpionellopsis oblonga (Cadisch, 1932); d, e, ae) Calpionellopsis simplex (Colom, 1939); f, g) Calpionellopsis sp. A; h-j) Calpionella elliptica Cadisch, 1932; k, l) Calpionella minuta Houša, 1990; m-o) Calpionella alpina Lorenz, 1902; p, q) Crassicollaria parvula Remane, 1962; r) Remaniella borzai Pop, 1994; s) Lorenziella hungarica Knauer and Nagy, 1964; t) Lorenziella plicata Le Hégarat and Remane, 1968; u) Tintinnopsella doliphormis (Colom, 1939); v) Tintinnopsella subacuta (Colom, 1948); w-y) Tintinnopsella carpathica (Murgeanu and Filipescu, 1933) (small varieties); z, aa) Tintinnopsella longa (Colom, 1939); abad, af-aj) Tintinnopsella carpathica (Murgeanu and Filipescu, 1933) (large varieties). Scale bars $=50 \mu \mathrm{m}$. 



1902 and Tintinnopsella carpathica (Murgeanu and Filipescu, 1933) (the latter one in both large and small varieties). There are also common Calpionella minuta Houša, 1990, Crassicollaria parvula Remane, 1962 and Tintinnopsella longa (Colom, 1939), as well as rare Calpionellopsis simplex (Co- lom, 1939), Calpionella elliptica Cadisch, 1932, Lorenziella hungarica Knauer and Nagy, 1964, L. plicata Remane, 1968, Remaniella borzai Pop, 1994, Tintinnopsella doliphormis (Colom, 1939) and T. subacuta (Colom, 1948) (see Figs 3, 4). Rare and often poorly preserved Longicollaria dobeni 
Fig. 5. Calcareous dinoflagellate cysts of the Dodelen-3 outcrop (Ticha Formation, sample Do-8, Stomiosphaera wanneri Zone, upper Berriasian): $a-c)$ Stomiosphaera wanneri Borza, 1969; d, e) Colomisphaera tenuis (Nagy, 1966); $f-h$ ) Committosphaera sublapidosa (Vogler, 1941); i-k) Stomiosphaerina proxima Řehánek, 1987; l) Colomisphaera carpathica (Borza, 1964); m-o) Colomisphaera fortis Řehánek, 1982; p-t) Cadosina fusca fusca Wanner, 1940; u) Cadosina fusca cieszynica Nowak, 1966; v-y) Cadosina minuta Borza, 1980; z, aa) Stomiosphaera moluccana Wanner, 1940; ab, ac) Colomisphaera cf. alpina (Leischner, 1959); ad) Colomisphaera lucida Borza, 1986. Scale bars $=50 \mu \mathrm{m}$.
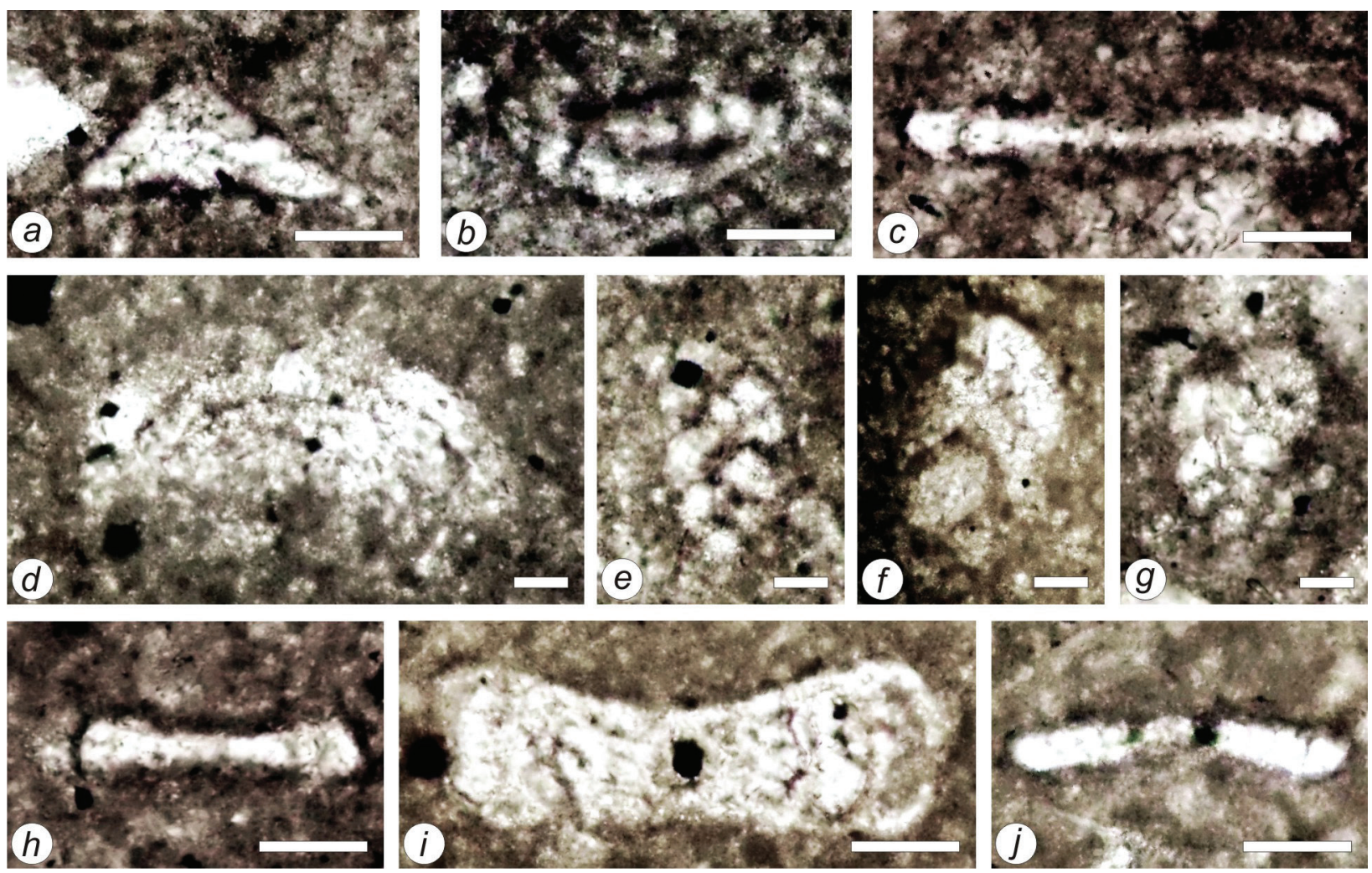

Fig. 6. Foraminifera of the Dodelen-3 outcrop (Ticha Formation, sample Do-8, upper Berriasian): a) Patellina subcretacea Cushman and Alexander, 1930; b) Protopeneroplis cf. banatica Bucur, 1993; c, d, h, i) Spirillina sp.; e) Praechrysalidina sp.; f) Uvigerinammina uvigeriniformis (Seibold and Seibold, 1960); g) Verneuilinoides cf. neocomiensis (Mjatliuk, 1939); j) Conicospirillina sp. Scale bars $=50 \mu \mathrm{m}$.

(Borza, 1966), Borziella slovenica (Borza, 1969), Chitinoidella boneti Doben, 1963, Chitinoidella elongata Pop, 1997, Tintinnopsella remanei Borza, 1969, Crassicollaria brevis Remane, 1962, Crassicollaria intermedia (Durand Delga, 1957), Crassicollaria massutiniana (Colom, 1948) and Crassicollaria colomi Doben, 1963 were also recorded. Taking into account the degree of preservation and quantity of the latter calpionellids, their presence is most likely due to resedimentation from upper Tithonian sediments. Similar mixture of microfossils of different ages in the sediments of the Ticha Formation was previously noted by Ivanova et al. (2002).
The calcareous dinocyst association is characterized by abundant representatives of Cadosina minuta Borza, 1980 and Cadosina fusca fusca Wanner, 1940. Stomiosphaera wanneri Borza, 1969, Stomiosphaerina proxima Řehánek, 1987, Stomiosphaera moluccana Wanner, 1940 and Committosphaera sublapidosa (Vogler, 1941) are less common. There are also rare Colomisphaera tenuis (Nagy, 1966), Colomisphaera fortis Řehánek, 1982, Colomisphaera cf. alpina (Leischner, 1959) and longranging Colomisphaera carpathica (Borza, 1964). Single Cadosina fusca cieszynica Nowak, 1966 and Colomisphaera lucida Borza, 1986 were also observed (Figs 3, 5). 
Foraminifera are rare but show relatively diverse morphology. The following species were found: $\mathrm{Pa}$ tellina subcretacea Gushman and Alexander, 1930, Protopeneroplis cf. bantica Bucur, 1993, Uvigerinammina uvigeriniformis (Seibold and Seibold, 1960), Verneuilinoides cf. neocomiensis (Mjatlink, 1939), as well as representatives of the genera Spirillina, Praechrysalidina and Conicospirillina.

Such types of microfossil assemblages have been described in many sequences of the European Tethyan areas (e.g., Wierzbowski and Remane, 1992; Blanc et al., 1992, 1994; Aguado et al., 2000; Grabowski et al., 2016). Therefore, it can be argued that the microfossil taxa identified herein have a clear Tethyan affinity.

\section{Microfacies}

Calpionellid-spicule wackestone microfacies type was recorded in the rocks of the Ticha Formation. It contains mainly fine-grained pelagic microfossils. They are mostly represented by calcified sponge spicules, calpionellids, calcareous dinoflagellate cysts, calcified radiolarians, Globochaete alpina Lombard, 1945, rare benthic foraminifera, thinshelled ostracods, crinoidal fragments and echinoderm bioclasts (Fig. $7 a-c$ ). Silt-sized quartz grains, angular mica flakes and framboidal pyrite, which creates nests and impregnates the bioclasts (Fig. $7 c$ ), are well represented (10-15\%). There are also rare glauconite grains, tiny dolomite rhombohedra and organic matter. Some of the calpionellids have dark micrite borders (Fig. 4a-c, g, o-q, af). According to Reháková (in: Bakhmutov et al., 2018), this is due to "the higher content of organic matter formed by bio-coagulation". The micritic matrix contains dissolution seams enriched in calcite and clay minerals, locally pigmented by Fe-oxyhydroxides, and rare bioturbation (Fig. $7 a, b$ ).
This microfacies may be referred to the Standard Microfacies Type 1 (SMF 1-Burrowed: "Burrowed bioclastic wackestone with abundant fine pelagic and benthic biodetritus”) of Flügel (2004). It occurs in basin and open-marine shelf settings. Abundant sponge spicules, together with other pelagic microfossils (calpionellids, calcareous dinoflagellate cysts, Globochaete alpina and radiolarians), ostracods, crinoids and echinoderms confirm an openmarine deep-water environment. The presence of small benthic foraminifera of the genera Patellina and Spirillina also indicates deep-water depositional settings (Barbu, 2005; Petrova et al., 2012). The bioturbation fabrics and micritic matrix characterize a setting with low sedimentation rates and predominant low-energy hydrodynamic conditions.

\section{BIOSTRATIGRAPHIC NOTES}

\section{Ammonite biostratigraphy}

The ammonite assemblage recorded in this study is exclusively composed of Tethyan taxa. It indicates the upper Berriasian Tirnovella alpillensis Zone ("Thurmanniceras" otopeta Subzone) from the standard ammonite zonation for the West Mediterranean Province of the Tethyan Realm (Reboulet et al., 2018). The ammonite association consists of abundant Bochianites B. (?) ambiguus, B. neocomiensis and Bochianites sp., and single representatives of Tirnovella cf. alpillensis, Thurmanniceras cf. otopeta, Fauriella donzei, Berriasella (Berriasella) ex gr. calisto, Berriasella (B.) ex gr. momtchilovi and Phylloceras (Hypophylloceras) cf. tethys tethys (Figs 3, 8-9). Similar assemblages were documented in Spain (Aguado et al., 2000), SE France (Blanc et al., 1992, 1994; Bulot and Thieuloy, 1995; Bulot et al., 1993, 1995), the Polish Carpathians
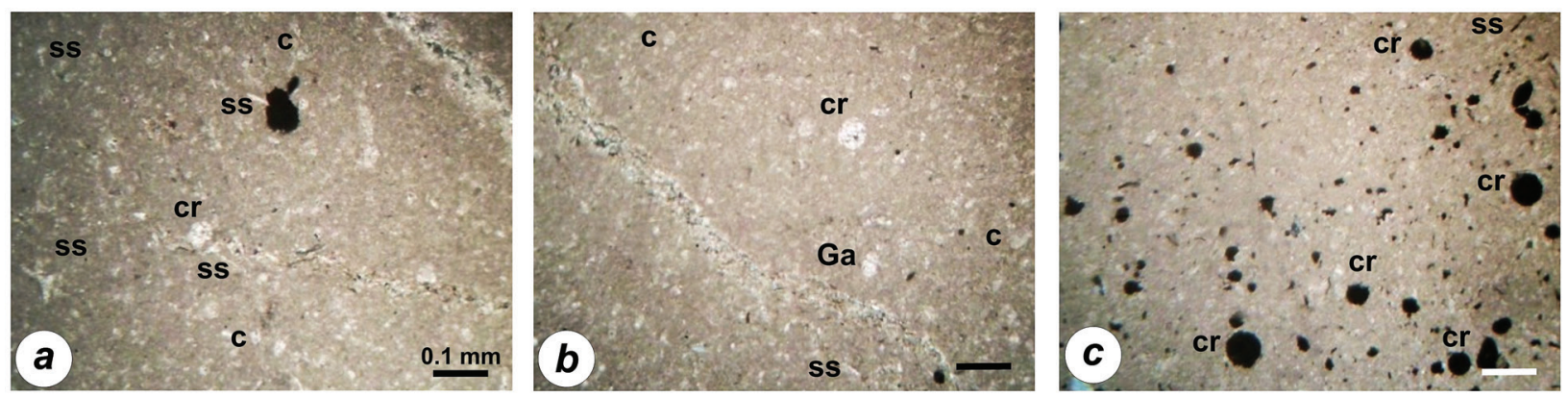

Fig. 7. Calpionellid-spicule wackestone (Ticha Formation, sample Do 8, upper Berriasian):

$a-b$ ) Calcified sponge spicules (ss) and radiolarians (cr), calpionellids (c), Globochaete alpina (Ga) and dissolution seams enriched in calcite and clay minerals, locally pigmented by Fe-oxyhydroxides; $c$ ) Micritic matrix containing replaced by opaque minerals (pyrite?) radiolarians (cr), sponge spicules (ss) and fine-grained biodetritus. Note: all images are in plane-polarized light. 

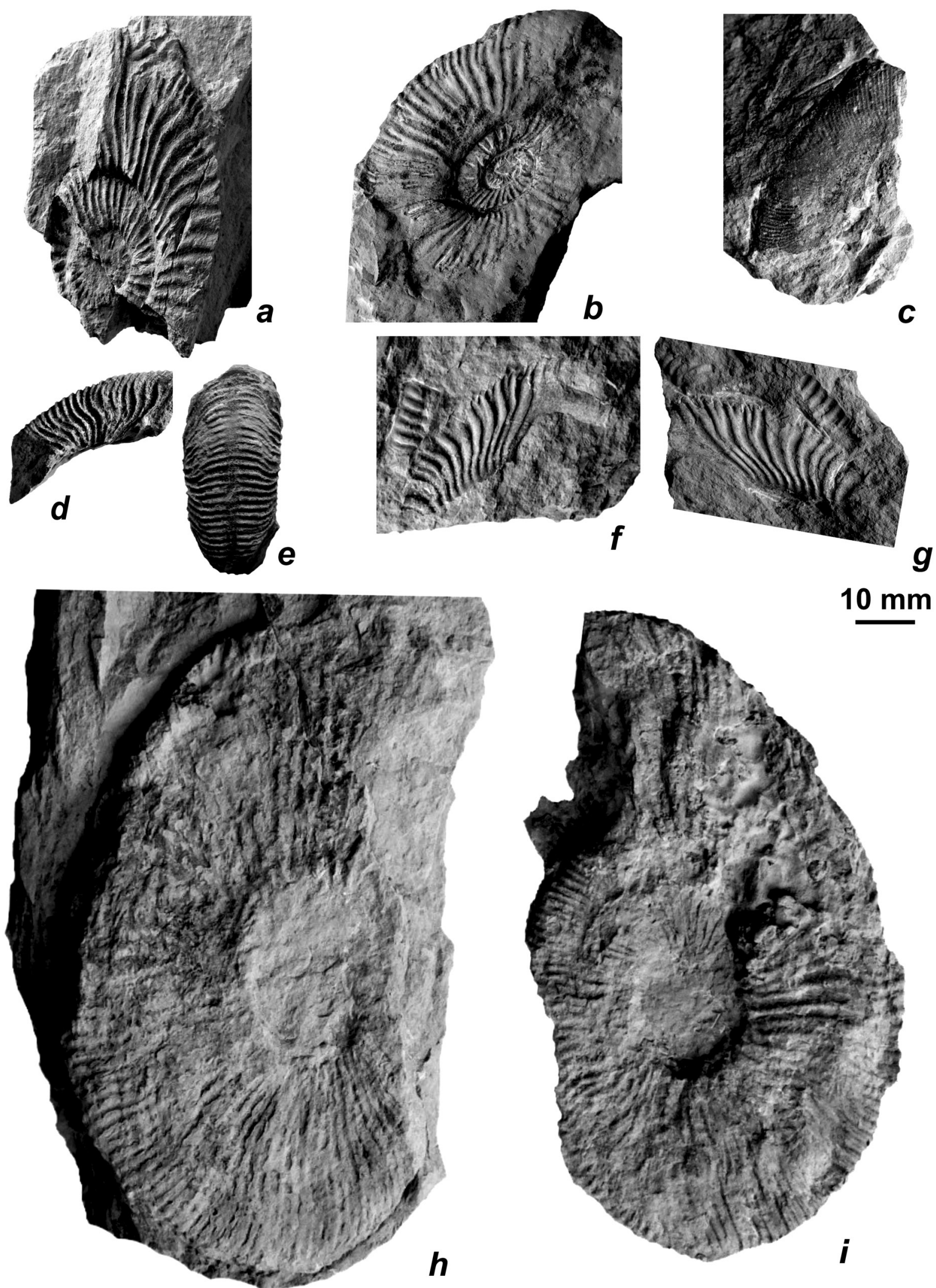

Fig. 8. Ammonites of the Dodelen-3 outcrop (Ticha Formation, uppermost Berriasian, Tirnovella alpillensis Zone, "Thurmanniceras” otopeta Subzone): a) Thurmanniceras cf. otopeta Thieuloy, 1979, specimen Do 3; b) Fauriella donzei (Le Hégarat, 1973), specimen Do 15; c) Phylloceras (Hypophylloceras) cf. tethys (d’ Orbigny, 1841), specimen Do 14; d, e) Berriasella (Berriasella) ex gr. momtchilovi (Nikolov, 1982), specimen Do 13; $f, g$ ) Berriasella (Berriasella) ex gr. calisto (d'Orbigny, 1850), specimen Do 11; $h$, i) Tirnovella cf. alpillensis (Mazenot, 1939), specimen Do 16. All figures are in natural size. 

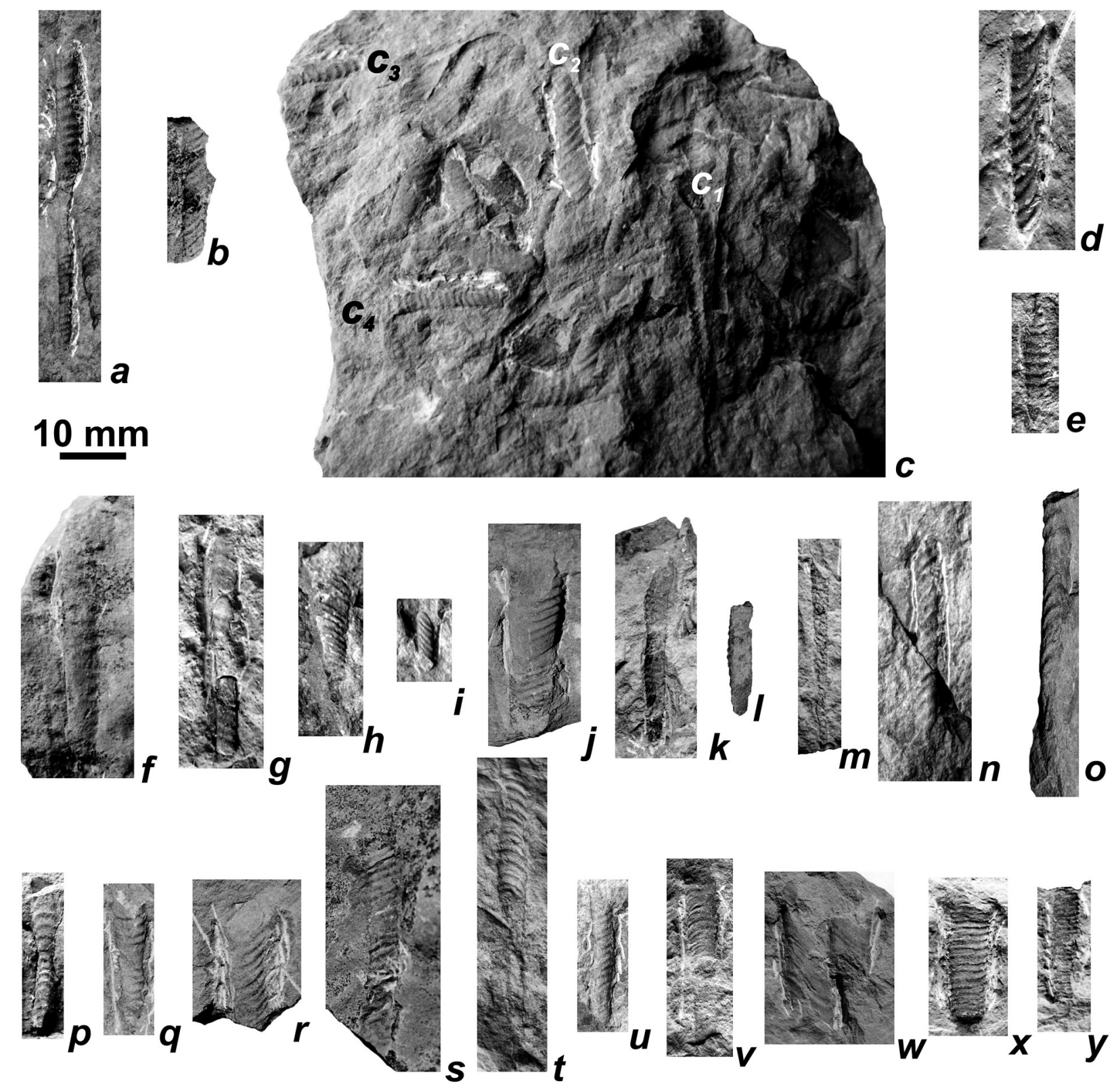

Fig. 9. Representatives of the genus Bochianites of the Dodelen-3 outcrop (Ticha Formation, upper Berriasian, Tirnovella alpillensis Zone, “Thurmanniceras” otopeta Subzone): a) Bochianites (?) ambiguus Arkadiev, Rogov and Perminov - Do 4a; $b, c$, $f$, $g-r)$ Bochianites neocomiensis (d’Orbigny, 1841), $b$ - Do 4c, $c-$ Do 5 ( $c_{1}-$ Do 5b, $c_{2}-$ Do 5c, $c_{3}-$ Do 5e, $c_{4}-$ Do 5d), $f-$ Do 7b, $g-i$ - Do 8a, Do 8c, Do 8d, $j$ - Do 9a, $k, l$ - Do 9b ( $k$ - negative, $l$ - fragment), $m$ - Do 9d, $n, o, p-$ Do 10 a, Do $10 \mathrm{~b}$, Do $10 \mathrm{f}, q-$ Do 9c, $r$ - Do 6b; $d$, e) Bochianites neocomiensis (d'Orbigny, 1841) morphotype tuberculatus Mandov, 1971, $d$ - Do 6a, $e$ - Do 10g; $s-w)$ Bochianites neocomiensis (d’Orbigny, 1841) morphotype goubechensis Mandov, 1971, s - Do 5a, $t-$ Do 6c, $u, v-$ Do 10d, 10e, $w$ - Do 17a, Do 17b; $x, y)$ Bochianites sp., $x$ - Do 7a, $y$ - Do 10c. All figures are in natural size.

(Wierzbowski and Remane, 1992; Pszczółkowski and Myczyński, 2004) and the Northern Calcareous Alps (Immel, 1987). In Bulgaria, the index-species of the "Thurmanniceras" otopeta Subzone was reported as single finds from the region of the town of Elena (Eastern Fore-Balkan Mts) (Nikolov, 1960) and SW from Borima Village (Central Fore-Balkan Mts) (Mandov, 1990).
The presence of Bochianites neocomiensis in the sediments of the Ticha Formation from the study area was first reported by Atanassoff (1961), unfortunately without figured specimens. The first figured upper Berriasian specimens of the genus Bochianites were those of Mandov (1971), from the western part of the Eastern Fore-Balkan Mts (near Yovkovtsi Village, in the vicinity of the town of 
Elena). Mandov (1975) further recorded abundant Bochianites fauna in the upper Berriasian sediments near Todyuvtsi Village, also in the region of the town of Elena. He reported the following taxa: Bochianites neocomiensis tuberculatus Mandov (mass occurrence); Bochianites cf. africanus (Tate) and Bochianites furcatocostatus Mandov. The representatives of Bochianites neocomiensis identified in this study can be partially attributed to Bochianites neocomiensis tuberculatus Mandov and Bochianites neocomiensis goubechensis Mandov. They confirm the presence of $B$. neocomiensis in the upper Berriasian of the Eastern Fore-Balkan Mts. Also, they are supporting evidence for the opinion of Arkadiev (2008), according to whom this species evolved in situ in Crimea at the lower Berriasian Jacobi Zone and gradually became common in the Central and Western European localities of the Valanginian and the Hauterivian.

Bochianites (?) ambiguus was recognized for the first time in Bulgaria. Its presence in the studied interval expands the stratigraphic range of the species to the top of the Berriasian ("Thurmanniceras" otopeta Subzone).

Herein, the earliest record of Phylloceras (Hypophylloceras) tethys tethys in Bulgaria was also noted. Previously, it was found only in Valanginian and Hauterivian sediments of the Western ForeBalkan Mts (Mandov, 1976), the Western Srednogorie and the Western Balkan Mts (Petrova, 2011). The appearance of the species in the Berriasian has also been recorded in France (Joly, 2000) and the Northern Calcareous Alps (Immel, 1987).

\section{Microfossil biostratigraphy}

The presence of Calpionellopsis oblonga and other diverse concomitant species in the calpionellid association indicates the upper Berriasian Oblonga Subzone of the Calpionellopsis Zone (sensu Pop 1994b, 1997b; Reháková and Michalík, 1997; Lakova and Petrova, 2013). Apart from the index-species, the taxa characteristic of this subzone are: Calpionellopsis sp. A; Lorenziella plicata; Calpionellopsis simplex; Calpionella elliptica; Lorenziella hungarica; Tintinnopsella doliphormis; Remaniella borzai; Tintinnopsella subacuta and Tintinnopsella longa (Figs 3, 4). In addition to these taxa, there are also long-ranging species, such as Tintinnopsella carpathica, Calpionella alpina, Crassicollaria parvula and Calpionella minuta. Both the composition of this assemblage and the large number of small and large forms of Tintinnopsella carpathica reveal that it corresponds to the middle part of the Oblonga Subzone (Grabowski et al., 2016).
Calcareous dinocysts are indicative of the upper Berriasian Stomiosphaera wanneri Zone (Lakova et al., 1999; Reháková, 2000; Grabowski et al., 2016; Ivanova and Kietzmann, 2017). Cadosina minuta and Cadosina fusca fusca are dominant. The representatives of Stomiosphaera wanneri (index-species), Stomiosphaera moluccana, Stomiosphaerina proxima and Committosphaera sublapidosa are common. The zonal association also includes Colomisphaera tenuis, $C$. fortis, $C$. carpathica, C. lucida, Colomisphaera cf. alpina and Cadosina fusca cieszynica (Figs 3, 5). The calcareous dinocyst assemblage is akin to that reported in the West Balkan Mts (Grabowski et al., 2016).

Additional elements of the fossil assemblage are the small benthic foraminifera. The foraminiferal taxa do not have biostratigraphic value for this locality since they are known to have too wide stratigraphical ranges. Their recorded ranges are as follows: Patellina subcretacea, upper Tithonian-Barremian (Petrova et al., 2012; KowalKasprzyk, 2016); Protopeneroplis cf. bantica, Berriasian-Aptian (Blanc et al., 1992; Bucur, 1997); Uvigerinammina uvigeriniformis, Oxfordian-lower Valanginian (Krajewski and Olszewska, 2007; Olszewska, 2010); and Verneuilinoides cf. neocomiensis, Tithonian-Aptian (Ivanova and Kołodziej, 2010; Ivanova et al., 2015; Bakhmutov et al., 2018). These taxa contribute to the available data by being dated as late Berriasian, based on the other coeval fossil groups.

\section{SYSTEMATIC PART}

The classification of the ammonites studied herein follows those of Joly (1993) and Klein et al. (2009) for phylloceratids; Klein (2005) for perisphinctids; and Company (1987), Vermeulen (2006) and Klein et al. (2007) for bochianitids. An asterisk indicates the type specimen of the species. Standard dimensions were measured and given both in millimeters and as percentages of the diameter in the text as follows: D (shell diameter), Wh (whorl height), U (umbilical width). Due to the strong deformation of the specimens, the measurements $\mathrm{Wb}$ (whorl breadth) are not included.

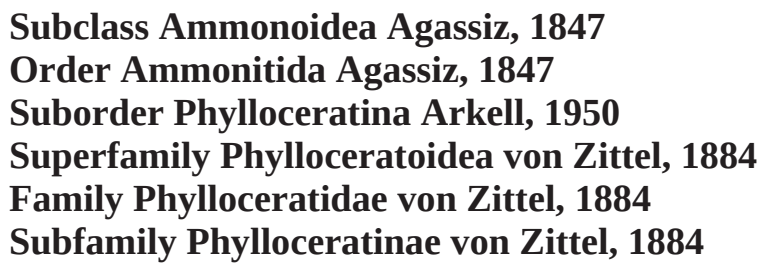


Genus Phylloceras Suess, 1865

Type species. Ammonites heterophyllus Sowerby, 1820.

\section{Subgenus Phylloceras (Hypophylloceras) Salfeld,} 1924

Type species. Phylloceras onoensis Stanton, 1896.

\section{Phylloceras (Hypophylloceras) cf. tethys tethys (d'Orbigny, 1841)}

(Fig. 8c)

*1841.Ammonites Thetys d’Orbigny, pp. 174-175, Pl. 53, Figs 7-9.

2009. Phylloceras (Hypophylloceras) tethys tethys (d’Orbigny): Klein et al., pp. 24-26 (cum syn.).

2010. Phylloceras tethys (d’Orbigny): Főzy et al., p. 529.

2011. Phylloceras (Hypophylloceras) tethys (d'Orbigny): Petrova, pp. 78-79, Pl. 1, Figs 1-4, 5a, b, 6, 7.

2012. Phylloceras thetys (d’Orbigny): Lukeneder, p. 4, Fig. 4Y.

2012. Phylloceras (Hypophylloceras) tethys (d’Orbigny): Joly and Mercier, p. 145, Figs 11a, b, 12a, b, 13a-c, 14a, b, 15-20.

2012. Phylloceras (Hypophylloceras) cf. tethys (d'Orbigny): Joly and Mercier, p. 147, Fig. 21a, b.

non 2013. Euphylloceras cf. thetys (d'Orbigny): Bujtor et al., p. 278, Fig. 4A [= ?Phylloceras (Hypophylloceras) serum].

2016. Phylloceras (Hypophylloceras) tethys (d’Orbigny): Lukeneder, p. 256, Fig. 6a.

Lectotype. The lectotype, designated and refigured by Joly (2000, pl. 35, fig. 4), is the original specimen of d'Orbigny (1841, pl. 53, figs 7-8), from the Valanginian of Saint-Julien-en-Beauchêne, HautesAlpes. It takes part of d'Orbigny's collection (coll. nr 4841B-1) kept at the Muséum national d'Histoire naturelle in Paris.

Material and record. A single fragment of calcareous mold (specimen Do 14), which corresponds to the body chamber. Ticha Formation, Dodelen-3 outcrop (20 cm above the base), Tirnovella alpillensis Zone, "Thurmanniceras" otopeta Subzone (see Fig. 3).

Measurements: $\mathrm{Wh}=19.5 \mathrm{~mm}$.

Description. Fragment of a small-sized involute and compressed ammonite, with high oval section and slightly convex whorl sides. The venter is rounded. The ornamentation is represented by dense, very thin radial ribs slightly projected forwards in the outer half of the whorl sides.

Remarks. The closest species to Phylloceras (Hypophylloceras) tethys tethys is Phylloceras (Hypophylloceras) serum (Oppel, 1865), but these taxa differ in section and suture-line (see Reboulet, 1996; Houša and Vašíček, 2004; Joly and Mercier, 2012). Ornamentation can be also taken as an additional criterion. The ribs of $P$. (H.) serum are straight, while those of $P$. (H.) tethys tethys are always slightly curved forwards in the outer half of the whorl sides.

Occurrence. Phylloceras (Hypophylloceras) tethys tethys is widespread from the Berriasian to the Barremian (inclusive) in the Tethyan region (Joly, 2000). The species has been reported from France, Italy, Spain, Germany, Austria, Switzerland, Hungary, Poland, Czech Republic, Slovakia, Romania, Serbia, Caucasus, Israel, Algeria, Tunisia, Madagascar, California and Bulgaria. This is the first record of this species in the Berriasian of Bulgaria. Up until now, it had been found only in sediments with Valanginian and Hauterivian age in the areas of the Western Fore-Balkan Mts, Western Balkan Mts and Western Srednogorie (Mandov, 1976; Petrova, 2011).

\section{Suborder Ammonitina Agassiz, 1847 Superfamily Perisphinctoidea Steinmann, 1890 Family Neocomitidae Salfeld, 1921 Subfamily Berriasellinae Spath, 1922}

\section{Genus Berriasella Uhlig, 1905}

Type species. Ammonites privasensis Pictet, 1867. Subgenus Berriasella (Berriasella) Uhlig, 1905 Type species. Same as for the genus.

\section{Berriasella (Berriasella) ex gr. momtchilovi (Nikolov, 1982) \\ (Fig. 8d,e)}

Material and record. Deformed fragment, part of the body chamber, transversely flattened (specimen Do 13). Ticha Formation, Dodelen-3 outcrop (10 $\mathrm{cm}$ above the base), Tirnovella alpillensis Zone, “Thurmanniceras" otopeta Subzone (see Fig. 3).

Measurements: Wh $\approx 14.5 \mathrm{~mm}$.

Description. Fragment of a small-sized, moderately evolute ammonite, with depressed subrectangular whorl section (due to the transverse flattening of the specimen). The whorl sides are slightly convex. The venter is rounded, with smooth groove. The ornamentation is represented by very thin, sharp and dense, gently flexuous, prorsiradiate ribs. A few ribs run single from the umbilical edge. Most of the ribs bifurcate at approximately $1 / 2$ of the height of the whorl. The ribs can both break and pass without interruption through the ventral area.

Remarks. The fragment is very close by size and style of ornamentation to Berriasella (Berriasella) momtchilovi (Nikolov) (1982, pl. 18, fig. 8), but its incompleteness does not allow full identification. 
Berriasella (Berriasella) ex gr. calisto (d'Orbigny, 1850)

(Fig. 8f, g)

Material and record. Fragment and a negative of the body chamber with preserved lappet (specimen Do 11). Ticha Formation, Dodelen-3 outcrop (10 cm above the base), Tirnovella alpillensis Zone, "Thurmanniceras” otopeta Subzone (see Fig. 3).

Measurements: $\mathrm{Wh}=17.5$.

Description. Small- to medium-sized ammonite. The section is subrectangular, with weakly convex walls. The ventral area and the umbilical edge are rounded. The sculpture is represented by thin and gently flexuous prorsiradiate ribs. Ribs start from the umbilical edge. Most of them bifurcate approximately at mid-flanks. A simple rib is also present. The aperture ends with a pronounced constriction and long spatula-shaped lateral lappet.

Remarks. The available specimen has all diagnostic features of Berriasella (Berriasella) calisto (d’Orbigny), but its incompleteness does not allow full species identification.

Subfamily Neocomitinae Salfeld, 1921

Genus Tirnovella Nikolov, 1966

Type species. Berriasella alpillensis Mazenot, 1939.

\section{Tirnovella cf. alpillensis (Mazenot, 1939)}

(Fig. 8h, i)

*1939. Berriasella alpillensis Mazenot, pp. 73-74, Pl. VI, Fig. 22a-c.

2005. Tirnovella alpillensis (Mazenot): Klein, pp. 253-254 (cum syn.).

2007. Tirnovella alpillensis (Mazenot): Arkadiev, pp. 115116, Pl. 1, Fig. 4.

2009. Tirnovella alpillensis (Mazenot): Cantú-Chapa, Fig 7n, o (= Howarth, 1992, Pl. 9, Figs 3, 4).

2011. Tirnovella alpillensis (Mazenot): Arkadiev, p. 11, Pl. 3, Fig. 8 (= Arkadiev, 2007, Pl. 1, Fig. 4).

2012. Tirnovella alpillensis (Mazenot): Arkadiev and Bogdanova, pp. 158-159, Pl. 7, Fig. 10 (= Arkadiev, 2007, Pl. 1, Fig. 4; Arkadiev, 2011, Pl. 3, Fig. 8).

2013. Tirnovella cf. alpillensis (Mazenot): Bujtor et al., p. 286, Fig. 5E, F.

2015. Tirnovella alpillensis (Mazenot): Boorová et al., p. 119, Fig. 10E.

Holotype. The holotype is the original specimen of Mazenot (1939, pl. 6, fig. 22a-c). It was refigured by Le Hégarat (1973, pl. 49, fig. 2) and Nikolov (1982, pl. 84, fig. 2). The holotype originates from the Berriasian of the Eyguières (Bouche-du-Rhône), SE France.

Material and record. Strongly laterally flattened calcareous mold, partially leached. The umbilical area is poorly preserved (specimen Do 16). Ticha Formation, Dodelen-3 outcrop (75 $\mathrm{cm}$ above the base), Tirnovella alpillensis Zone, "Thurmanniceras” otopeta Subzone (see Fig. 3).

Measurements: $\mathrm{D}=109 \mathrm{~mm}, \mathrm{Wh} \approx 46 \mathrm{~mm}, \mathrm{U}=$ $28.5 \mathrm{~mm}, \mathrm{Wh} / \mathrm{D}=0.42, \mathrm{U} / \mathrm{D}=0.26$.

Description. Medium-sized and moderately evolute ammonite, with compressed, subtrapezoidal whorl section. The venter is narrow, with smooth band. Despite the poor preservation of the specimen, there is a clear difference in the ornamentation on the phragmocone and the body chamber. The sculpture on the phragmocone is represented by very fine and dense ribs, typically running in pairs from small umbilical tubercles, or occurring as single ribs without tubercles between the paired ribs. The bulk of the ribs bifurcate at the middle or at the upper part of the whorl. All ribs interrupt at the ventral area. The body chamber is characterized by the same style of ornamentation as that in the inner whorls, but the ribs are stronger and gently flexuous, with wider intervals between them. In addition, the umbilical nodes are stronger and more pronounced.

Remarks. The species is closest to Tirnovella subalpina (Mazenot, 1939). The differences between the two types were commented by Le Hégarat (1973), Nikolov (1982) and Tavera (1985).

Occurrence. This species is typical for the upper part of the upper Berriasian in the Mediterranean Province (Reboulet et al., 2018). Tirnovella alpillensis is known from France, Spain, Italy, Austria, Hungary, Bulgaria, Crimea, Georgia, Iraq, Algeria, Tunisia and Morocco.

\section{Genus Thurmanniceras Cossmann, 1901}

Type species. Ammonites thurmanni Pictet and Campiche, 1860.

\section{Thurmanniceras cf. otopeta Thieuloy, 1979}

(Fig. 8a)

2005. Thurmanniceras otopeta Thieuloy: Klein, p. 278 (cum syn.).

?2013. Thurmanniceras sp. aff. otopeta Thieuloy: Bujtor, p. 9, Fig. 5I.

2015. Thurmanniceras otopeta Thieuloy: Boorová et al., p. 119, Fig. 10A.

Holotype. The holotype is the original specimen of Thieuloy (1979, pl. 1, fig. 1). It comes from the lower Valanginian of the Barret-le-Bas, Les Sausses (Hautes-Alpes). The specimen (ID 10059) takes part of Thieuloy's collection, kept at the University of Grenoble.

Material and record. One mold with deformed sculpture and poorly preserved umbilical area (speci- 
men Do 3). Ticha Formation, Dodelen-3 outcrop (the very base), Tirnovella alpillensis Zone, "Thurmanniceras” otopeta Subzone (see Fig. 3).

Measurements: $\mathrm{Wh}=25.5 \mathrm{~mm}, \mathrm{U}=14 \mathrm{~mm}$.

Description. Deformed, small-sized, moderately evolute ammonite. The whorl section is compressed, subtrapezoidal. The walls are weakly convex. The umbilical edge is rounded. The venter is narrow, with smooth groove. The ornamentation in the inner whorls is represented by dense and thin radial ribs, starting from the umbilical edge. The bulk of the ribs bifurcate approximately at mid-flanks. The ribs on the body chamber are stronger, wider, rounded and gently flexuous. Most of them are bipartite, but there is also one tripartite rib. All ribs break in the ventral area.

Remarks. The specimen is very close to those figured by Company (1987), especially to that in his pl. 5, fig. 6.

Occurrence. Thurmanniceras otopeta occurs at the uppermost part of the Berriasian in the Mediterranean area (Reboulet et al., 2018). It has been found in France, Spain, Austria, Poland, Hungary, Romania and Bulgaria.

\section{Genus Fauriella Nikolov, 1966}

Type species. Berriasella gallica Mazenot, 1939.

\section{Fauriella donzei (Le Hégarat, 1973)}

(Fig. 8b)

*1973. Tirnovella donzei Le Hégarat, pp. 183-185, Pl. 27, Figs 5, 7, 8; Pl. 49, Fig. 6.

2005. Fauriella donzei (Hégarat): Klein, p. 261 (cum syn.).

2013. Fauriella donzei (Le Hégarat): Bujtor et al., p. 287, Fig. 5L.

Holotype. The holotype (ID 538) was figured by Le Hégarat (1973, pl. 49, fig. 6) and comes from the Berriasian of Sarcenas, SE France. It is stored at the University of Grenoble. The holotype was refigured by Nikolov (1982, pl. 86, fig. 3).

Material and record. One deformed, partially leached mold, with incompletely preserved sculpture (specimen Do 15). Ticha Formation, Dodelen-3 outcrop (50 cm above the base), Tirnovella alpillensis Zone, "Thurmanniceras" otopeta Subzone (see Fig. 3).

Measurements: $\mathrm{D}=55 \mathrm{~mm}, \mathrm{Wh}=21 \mathrm{~mm}, \mathrm{U}=17.5$ $\mathrm{mm}, \mathrm{Wh} / \mathrm{D}=0.38, \mathrm{U} / \mathrm{D}=0.32$.

Description. Small-sized and moderately evolute specimen. The whorl section is compressed, subtrapezoidal. The walls are weakly convex. The umbilical edge is rounded and poorly preserved on the last whorl. The venter is narrow, with smooth band.
The sculpture is represented by thin and densely arranged radial ribs, running either as single or in pairs from the umbilical edge. The bulk of ribs bifurcate approximately at the middle part of the whorl, but there are also rare simple rips. The pairs of ribs start from small umbilical tubercles. They are rare on the phragmocone, but on the last whorl their number is significantly increasing. All ribs are flexuous on the body chamber.

Remarks. Similarities with other species were discussed in detail by Le Hégarat (1973), Nikolov (1982) and Tavera (1985).

Occurrence. Fauriella donzei is a characteristic species for the upper Berriasian. According to Tavera (1985), it occurs in the Boissieri Zone, but Vašíček et al. (1999) fixed it also around the Berriasian/Valanginian boundary (Thurmanniceras otopeta/Thurmanniceras pertransiens zones). The species has been found in France, Spain, Austria and Bulgaria.

Suborder Protancyloceratina Vermeulen, 2005

Superfamily Bochianitoidea Spath, 1922

Family Bochianitidae Spath, 1922

Subfamily Bochianitinae Spath, 1922

\section{Genus Bochianites Lory, 1898}

Type species. Baculites neocomiensis d'Orbigny, 1842.

\section{Bochianites (?) ambiguus Arkadiev, Rogov and Perminov, 2011}

(Fig. 9a)

?1975. Bochianites sp.: Mandov, pp. 49-50, Pl. 1, Figs 11, 13, 14.

2008. Bochianites goubechensis Mandov, 1971: Arkadiev, p. 474, Pl. 3, Fig. 6a, b.

*2011. Bochianites (?) ambiguus Arkadiev, Rogov and Perminov, pp. 392-394, Pl. 5, Fig. 1a, b, 2a, b, 3a, b.

2012. Bochianites (?) ambiguus Arkadiev, Rogov and Perminov: Arkadiev and Bogdanova, pp. 222-223, Pl. 39, Figs 1a, b, 2a, b, 3a, b (= Arkadiev, Rogov and Perminov, 2011, Pl. 5, Figs 1a, b, 2a, b, 3a, b).

?2016. Bochianites cf. ambiguus Arkadiev, Rogov and Perminov: Hoedemaeker et al., pp. 160-161, Pl. 14, Fig. 8.

Holotype. The holotype is the original specimen of Arkadiev, Rogov and Perminov (2011, pl. 5, fig. 3a, b, coll. nr 1/13217). It comes from the Berriasian (Jacobi Zone, Grandis Subzone) of Eastern Crimea, Feodosiya, Cape St Elias. The holotype is from the collection of V.A. Perminov, kept at the Museum of the Russian Geological Research Institute, St Petersburg (Russia).

Material and record. One fragmentary sculptured mold (specimen Do 4a). Ticha Formation, Dodel- 
en-3 outcrop (the very base), Tirnovella alpillensis Zone, “Thurmanniceras” otopeta Subzone (see Fig. 3).

Measurements. The specimen is $46 \mathrm{~mm}$ long.

Description. Baculicone, with elliptical, laterally compressed section. Ornamentation is represented by relatively dense, evenly distributed, rounded single ribs, forming an angle of $15^{\circ}$ to the axis of the shell. Near the aperture, there is a well-defined constriction parallel to the ribbing, surrounded by ribs with a slightly more pronounced relief.

Remarks. The specimen is very close in morphology to the fragments figured by Mandov (1975), especially to the one in his pl. 1, fig.13. It differs from the specimens of the type series (Arkadiev et al., 2011) by the presence of only one constriction, but this may be due to the small size of the specimen and its relatively poor preservation.

Occurrence. Berriasian, Crimea, Spain and Bulgaria. According to Arkadiev et al. (2011) and Hoedemaeker et al. (2016), Bochianites (?) ambiguus occurs in the Jacobi ammonite Zone. Mandov (1975) also refers his Bochianites sp. fragments to the lower Berriasian. The present material extends the stratigraphical distribution of the species to the top of the Berriasian.

\section{Bochianites neocomiensis (d'Orbigny, 1842)}

(Fig. 9b-w)

*1842. Baculites neocomiensis d’Orbigny, p. 560, Pl. 138, Figs 1-5 (compilation of several specimens).

2007. Bochianites neocomiensis (d’Orbigny): Klein et al., pp. 5-7 (cum syn.).

2008. Bochianites neocomiensis (d'Orbigny): Arkadiev, pp. 471-472, Pl. 3, Figs 1-3, 4a-c, 5a-c, Text-figs 2a, 3b, $4 \mathrm{~b}$.

2008. Janenschites oosteri (Sarasin and Schöndelmayer): Arkadiev, p. 475, Pl. 3, Figs 12a-d, Text-figs 3e, 4b.

2008. Bochianites oosteri Sarasin and Schöndelmayer: Arkadiev, Text-figs 4a, c, d.

2011. Bochianites neocomiensis (d'Orbigny): Petrova, pp. 9091, Pl. 4, Figs 7-11, 12a, b.

2011. Bochianites goubechensis Mandov: Petrova, pp. 91-92, Pl. 5, Fig. 3.

2012. Bochianites neocomiensis (d’Orbigny): Arkadiev and Bogdanova, pp. 218-219, Pl. 38, Figs 1-3, 4a-c, 5a-c, (= Arkadiev, 2008, Pl. 3, Figs 1-3, 4a-c, 5a-c), Textfig. 76b (= Arkadiev, 2008, Text-fig. 3b).

2020. Bochianites oosteri Sarasin and Schöndelmayer: Vašíček, p. 77, Fig. 2A.

2020. Bochianites neocomiensis (d’Orbigny): Vašíček, Fig. 2B.

Lectotype. The lectotype (nr LPMP-R734) was designated by Busnardo (in Gauthier, 2006, p. 164, pl. 9, fig. 4, text-fig. 73a, 73b). It is from upper Val- anginian of Lioux près de Senez (Alpes-de-HauteProvence). It takes part of d'Orbigny's collection (coll. nr 4883-1) kept at the Muséum national d'Histoire naturelle in Paris.

Material and record. Thirty-three fragmentary, laterally compressed, sculptured molds and imprints representing both juvenile shells and larger adult shells (specimens Do 4b, c, Do 5a-f, Do 6a-c, Do 7b, Do 8a-d, Do 9a-e, Do 10a, b, d, Do 10e-k, Do 17a, b). Ticha Formation, Dodelen-3 outcrop (the very base and $100 \mathrm{~cm}$ above the base), Tirnovella alpillensis Zone, “Thurmanniceras” otopeta Subzone (see Fig. 3).

Measurements. The largest fragment (Do 4b) is 51 mm long.

Description. The conch is straight, with oval section, but the bulk of the fragments have elliptical section due to lateral compression. The dorsal side is smooth. The ornamentation is represented by thin, simple and evenly distributed annular, oblique ribs, which cross the ventral region without interruption and form an arcuate bend in the direction of the aperture. In some specimens (Do 6a and Do $10 \mathrm{~g}$ ), a tubercular swelling on the ribs occurs in the ventral region, while, in others, there are clearly expressed constrictions parallel to the ribbing, as the ribs on both sides of the constriction have a more pronounced relief (specimens Do 5a, Do 6c, Do 10d, Do 10e, Do 17a, b). The suture line is not preserved.

Remarks. Herein, the broad conception of the species proposed by Company (1987) and Klein et al. (2007) is adopted. However, since this is most likely a case of intraspecific variability, it may be good to give the variations as morphotypes as suggested by Reboulet (1996). Thus, specimens that show differences from the type species can be attributed to Bochianites neocomiensis (d'Orbigny) morphotype tuberculatus Mandov and Bochianites neocomiensis (d'Orbigny) morphotype goubechensis Mandov.

According to other authors (Vašíček, 1999, 2020; Houša and Vašíček, 2004; Arkadiev, 2008), Bochianites neocomiensis and Bochianites oosteri are two completely separate species, which differ in their sculpture, suture lines, sizes and stratigraphical ranges. Arkadiev (2008) even includes representatives of Bochianites oosteri in the genus Janenschites.

Occurrence. Bochianites neocomiensis is widespread from the Berriasian to the lower Barremian in the Tethyan and Boreal realms (Arkadiev, 2008). The species has been reported from France, Spain, Italy, Switzerland, Austria, Hungary, the Czech Republic, Poland, Romania, Bulgaria, Crimea, Caucasus, Morocco, Tunisia, Siberia, Germany, England, Greenland and Antarctica. 


\section{Bochianites sp.}

(Fig. 9x-y)

Material and record. Three fragments, two of them are sculptured molds (specimens Do $5 \mathrm{~g}$ and Do 10c), and one is with a very thin preserved shell (specimen Do 7a). Ticha Formation, Dodelen-3 outcrop (the very base), Tirnovella alpillensis Zone, “Thurmanniceras” otopeta Subzone (see Fig. 3).

Measurements. The fragments are 11-19 mm long and 5.5-7.5 mm wide.

Description. The specimens are small parts of straight ammonites with oval cross-section. The sculpture is represented by very dense, fine, evenly spaced ribs, perpendicular to the axis of the shell.

Remarks. These ammonites are close to Bochianites (?) ambiguus, but are characterized by finer and more dense ribbing, lack of constrictions, and perpendicular location of the ribs relative to the axis of the shell. A similar specimen from the lower Berriasian was figured as Bochianites sp. by Mandov (1975, pl. 1, fig. 12).

\section{CONCLUSION}

The combined fossil data reveal a late Berriasian age for the studied interval of the Ticha Formation. The indicated presence of the "Thurmanniceras" otopeta ammonite Subzone, the calpionellid Oblonga Sub- zone and the calcareous dinocyst Stomiosphaera wanneri Zone points to the upper parts of the upper Berriasian. The fossil data are completely comparable to those from the Western Balkan Mts in Bulgaria, SE Spain, SE France, Polish Carpathians and the Northern Calcareous Alps. The earliest appearance of Phylloceras (Hypophylloceras) tethys tethys was also recorded and the first appearance of Bochianites neocomiensis was confirmed in the upper Berriasian of the Eastern Fore-Balkans in Bulgaria. The stratigraphical range of Bochianites (?) ambiguus was extended to the uppermost Berriasian.

\section{Acknowledgements}

The author is very grateful to official journal reviewers Prof. Miguel Company (University of Granada, Spain) and one anonymous reviewer, and also to Prof. Jaap Klein (Naturalis Biodiversity Center, Netherlands) for valuable comments and useful suggestions during the review process. I would like to thank my colleagues Lubomir Metodiev, Docho Dochev, Polina Andreeva and Hristo Kiselinov for their assistance in field research. Drs Georgi Granchovski and Lubomir Metodiev (Geological Institute, Bulgarian Academy of Sciences) are thanked for improving the language construction of the manuscript. This study is supported by the Project DMU 03/64, financed by the National Science Fund.

\section{REFERENCES}

Aguado, R., Company, M., Tavera, J.M. 2000. The Berriasian/ Valanginian boundary in the Mediterranean region: new data from the Caravaca and Cehegín sections, SE Spain. Cretaceous Research 21, 1-21.

Arkadiev, V.V. 2007. Some Upper Berriasian ammonites of the Crimean Mountains. In: Prozorovsky, V.A. (Ed.), Voprosi stratigrafii, paleontologii i paleogeografii (posvyashcheyetsya 100-letiya so dnya rozhdeniya professor G. Ya. Krymgol'tsa), Sankt-Peterburg University, Sankt-Peterburg, 103-117 (in Russian, with English summary).

Arkadiev, V.V. 2008. Representatives of the family Bochianitidae (Ammonoidea) from the Lower Cretaceous of the Crimean Mountains. Paleontological Journal 42 (5), 468-478.

Arkadiev, V.V. 2011. Predstaviteli rodov Fauriella, Tirnovella i Jabronella (Neocomitidae, Ammonoidea) iz berriasa Gornogo Kryma i ikh stratigraficheskoye znacheniye. Vestnik Sankt-Peterburgskogo universiteta 7 (2), 3-20 (in Russian).

Arkadiev, V.V., Bogdanova, T.N. 2012. Golovonogiye mollyuski (Ammonity). In: Arkadiev, V.V., Bogdanova, T.N. (Eds), Berriasian Stage of the mountainous Crimea. Izdatel'stvo "LEMA”, Sankt-Peterburg, 123-233 (in Russian, with English abstract).
Arkadiev, V.V., Rogov, M.A., Perminov, V.A. 2011. New occurrences of heteromorph ammonites in the BerriasianValanginian of the Crimean Mountains. Paleontological Journal 45 (4), 390-396.

Atanassoff, A. 1961. Géologie du secteur maritime des Prébalkans et de la vallée de la Kamčia. Travaux sur la géologie de Bulgarie, Série Stratigraphie et tectonique 2, 99-157 (in Bulgarian, with Russian and French abstracts).

Bakhmutov, V.G., Halásová, E., Ivanova, D.K., Józsa, Š., Reháková, D., Wimbledon, W.A.P. 2018. Biostratigraphy and magnetostratigraphy of the uppermost Tithonian-Lower Berriasian in the Theodosia area of Crimea (southern Ukraine). Geological Quarterly 62 (2), 197-236.

Barbu, V. 2005. Lower Cretaceous small benthic foraminifera from the Bucegi Mountains (South Carpathians) - paleoecological implications. Proceedings of the Romanian Academy, Series B 1, 29-36.

Blanc, E., Arnaud-Vanneau, A., Arnaud, H., Bulot, L., Gidon, M., Thieuloy, J.-P., Remane, J. 1992. Les couches du passage du Berriasien au Valanginien dans le secteur du Fontanil (Isère, France). Géologie Alpine 68, 3-12.

Blanc, E., Bulot, L., Paicheler, J.-C. 1994. La coupe de référence de Montbrun-les-Bains (Drôme, SE France): un 
stratotype potentiel pour la limite Berriasien-Valanginien. Comptes rendus de l'Académie des Sciences de Paris, Série II 318, 101-108.

Boorová, D., Skupien, P., Vašíček, Z., Lobitzer, H. 2015. Biostratigraphy of the Lower Cretaceous Schrambach Formation on the classical locality of Schrambachgraben (Northern Calcareous Alps, Salzburg Area). Bulletin of Geosciences 90 (1), 89-131.

Borza, K. 1969. Die Mikrofazies und Mikrofossilien des Oberjuras und der Unterkreide der Klippenzone der Westkarpaten. Slovak Academy of Sciences Publishing House, Bratislava, 302 pp.

Bucur, I.I. 1997. Representatives of the genus Protopeneroplis (Foraminifera) in the Jurassic and Lower Cretaceous deposits in Romania. Comparisons with other region of the Tethyan area. Acta Palaeontologica Romaniae 1, 65-71.

Bujtor, L. 2013. Valanginian perisphinctid ammonites from the Kisújbánya Basin (Eastern Mecsek Mts., Hungary). Cretaceous Research 41, 1-16.

Bujtor, L., Krische, O., Gawlick, H.-J. 2013. Late Berriasian ammonite assemblage and biostratigraphy of the Leube quarry near Salzburg (Northern Calcareous Alps, Austria). Neues Jahrbuch für Geologie und Paläontologie Abhandlungen 267 (3), 273-295.

Bulot, L.G., Thieuloy, J.-P. 1995. Les biohorizons du Valanginien du Sud-Est de la France: un outil fondamental pour les corrélations au sein de la Téthys occidentale. Géologie Alpine, Mémoire Hors Serie 20 (1994), 15-41.

Bulot, L.G., Blanc, E., Thieuloy, J.-P., Remane, J. 1993. La limite Berriasien-Valanginien dans le Sud-Est de la France: données biostratigraphiques nouvelles. Comptes rendus de l'Académie des Sciences de Paris, Série II 316, 1771-1778.

Bulot, L.G., Thieuloy, J.-P., Arnaud, H., Delanoy, G. 1995. The Lower Cretaceous Cephalopod Team First Field Meeting (Digne, 1990). The Lower Cretaceous of the South Vocontian basin and margins. Géologie Alpine, Mémoire Hors Série 20 (1994), 383-399.

Busnardo, R. 2006. Bochianites neocomiensis (d'Orbigny, 1842). In: Fischer J.-C., Gauthier, H. (Eds), Révision critique de la paléontologie française d'Alcide d'Orbigny. Volume IV. Céphalopodes crétacé. Backhuys Publishers Leiden, Pays-Bas, p. 164, pl. 9, fig. 4, text-fig. 73a, b.

Cantú-Chapa, A. 2009. Ammonites of the Cretaceous Taraises and lower Tamaulipas formations in eastern Mexico. In: Bartolini, C., Román Ramos, J.R. (Eds), Petroleum Systems in the Southern Gulf of Mexico, AAPG Memoir 90, 191-216.

Company, M. 1987. Los ammonites del Valanginiense del sector oriental de las Cordilleras Béticas (SE de España). $\mathrm{PhD}$ thesis, University of Granada, 294 pp. (in Spanish).

Dabovski, C., Zagorchev, I. 2009. Introduction: Mesozoic evolution and Alpine structure. In: Zagorchev, I., Dabovski, C., Nikolov, T. (Eds), Geology of Bulgaria. Vol. II. Mesozoic geology. "Prof. Marin Drinov" Academic Press, Sofia, 1337 (in Bulgarian, with English summary).

Doben, K. 1963. Über Calpionelliden an der Jura/Kreide Grenze. Mitteilungen der Bayerischen Staatssammlung für Paläontologie und Historische Geologie 3, 35-50.

d'Orbigny, A.D. 1840-1842. Paléontologie française. Description zoologique et géologique de tous les animaux mollusques et rayonnés fossiles de France. Terrains Crétacés. Vol. 1. Céphalopodes. Arthus-Bertrand, d’Orbigny, Paris, 662 pp.: 1-120 (1840); 121-430 (1841); 431-662 (1842).

Dunham, R.J. 1962. Classification of carbonate rocks according to depositional texture. In: Ham, W.E. (Ed.), Classification of Carbonate Rocks. American Association of Petroleum Geologists, Memoir 1, 108-121.
Flügel, E. 2004. Microfacies of Carbonate Rocks. Springer, Berlin, 976 pp.

Főzy, I., Janssen, N.M.M., Price, G.D., Knauer, J., Pálfy, J. 2010. Integrated isotope and biostratigraphy of a Lower Cretaceous section from the Bakony Mountains (Transdanubian Range, Hungary): A new Tethyan record of the Weissert event. Cretaceous Research 31, 525-545.

Grabowski, J., Lakova, I., Petrova, S., Stoykova, K., Ivanova, D., Wójcik-Tabol, P., Sobień, K., Schnab, P. 2016. Paleomagnetism and integrated stratigraphy of the Upper Berriasian hemipelagic succession in the Barlya section Western Balkan, Bulgaria: Implications for lithogenic input and paleoredox variations. Palaeogeography, Palaeoclimatology, Palaeoecology 46, 156-177.

Hoedemaeker, P.J., Janssen, N.M.M., Casellato, C.E., Gardin, S., Reháková D., Jamrichová, M. 2016. Jurassic/Cretaceous boundary in the Río Argos succession (Caravaca, SE Spain). Revue de paléobiologie 35 (1), 111-247.

Houša, V., Vašíček, Z. 2004. Ammonoidea of the Lower Cretaceous Deposits (Late Berriasian, Valanginian, Early Hauterivian) from Štramberk, Czech Republic. GeoLines 18, 7-57.

Howarth, M.K. 1992. Tithonian and Berriasian ammonites from the Chia Gara Formation in northern Iraq. Palaeontology 35 (3), 597-655.

Immel, H. 1987. Die Kreideammoniten der nördlichen Kalkalpen. Zitteliana 15, 3-163.

Ivanova, D., Bonev, N., Chatalov, A. 2015. Biostratigraphy and tectonic significance of lowermost Cretaceous carbonate rocks of the Circum-Rhodope Belt (Chalkidhiki Peninsula and Thrace region, NE Greece). Cretaceous Research 52, 25-63.

Ivanova, D., Kietzmann, D. 2017. Calcareous dinoflagellate cysts from the Tithonian-Valanginian Vaca Muerta Formation in the southern Mendoza area of the Neuquén Basin, Argentina. Journal of South American Earth Sciences 77, 150-169.

Ivanova, D., Kołodziej, B. 2010. Late Jurassic-Early Cretaceous foraminifera from Stramberk-type limestones, Polish Outer Carpathians. Studia Universitatis Babeş-Bolyai, Geologia 55 (2), 3-31.

Ivanova, D., Lakova, I., Pavlishina, P., Koleva-Rekalova, E. 2002. Joint biostratigraphy and lithofacies of Berriasian and Valanginian limestones from subsurface sections in NE Bulgaria. Geologica Balcanica 32 (2-4), 63-67.

Joly, B. 1993. Les Phyllocerataceae malgaches au Crétacé (Phylloceratina, Ammonoidea). Documents des Laboratoires de Géologie de la Faculté des Sciences de Lyon 127, 1-171 (in French, with English abstract).

Joly, B. 2000. Les Juraphyllitidae, Phylloceratidae, Neophylloceratidae (Phyllocerataceae, Phylloceratina, Ammonoidea) de France au Jurassique et au Crétacé. Geobios, Mémoire Spécial 23, et Mémoire de la Société Géologique de France 174, 1-204.

Joly, B., Mercier, P. 2012. Étude des faunes de Phylloceratoidea des marnes valanginiennes de Senez-Lioux (Alpesde-Haute-Provence). Comparaison avec quelques localités de la Drôme et de l'Ardèche. Carnets de géologie, Mémoire $1,137-172$

Klein, J. 2005. Lower Cretaceous Ammonites I. Perisphinctaceae 1: Himalayitidae, Olcostephanitidae, Holcodiscidae, Neocomitidae, Oosterellidae. In: Riegraf, W. (Ed.), Fossilium catalogus I: Animalia 139, Backhuys Publishers, Leiden, 1-484.

Klein, J., Busnardo, R., Company, M., Delanoy, G., Kakabadze, M., Reboulet, S., Ropolo, P., Vašiček, Z., Vermeulen, J. 2007. Lower Cretaceous Ammonites III. Bochianitoidea, 
Protancyloceratoidea, Ancyloceratoidea, Ptychoceratoidea. In: Riegraf, W. (Ed.), Fossilium catalogus I: Animalia 144, Backhuys Publishers, Leiden, 1-381.

Klein, J., Hoffmann, R., Joly, B., Shigeta, Y., Vašiček, Z. 2009. Lower Cretaceous Ammonites IV: Boreophylloceratoidea, Phylloceratoidea, Lytoceratoidea, Tetragonitoidea, Haploceratoidea including the Upper Cretaceous representatives. In: Riegraf, W. (Ed.), Fossilium catalogus I: Animalia 146, Backhuys Publishers, Leiden, Margraf Publishers, Weikersheim, 1-416.

Kowal-Kasprzyk, J. 2016. Micropaleontological description of exotics of the Mesozoic calcareous rocks from the Silesian Nappe between the Soła and Dunajec rivers. PhD thesis, Jagiellonian University, Krakow, 310 pp. (in Polish, with English abstract).

Krajewski, M., Olszewska, B. 2007. Foraminifera from the Late Jurassic and Early Cretaceous carbonate platform facies of the southern part of the Crimea Mountains; Southern Ukraine. Annales Societatis Geologorum Poloniae 77, 291-311.

Lakova, I., Petrova, S. 2013. Towards a standard Tithonian to Valanginian calpionellid zonation of the Tethyan Realm. Acta Geologica Polonica 63 (2), 201-222.

Lakova, I., Stoykova, K., Ivanova, D. 1999. Calpionellid, nannofossil and calcareous dinocyst bioevents and integrated biochronology of the Tithonian to Valangian in the Western Balkanides, Bulgaria. Geologica Carpathica 50 (2), 151-168.

Lakova, I., Tchoumatchenco, P., Ivanova, D., Koleva-Rekalova, E. 2007. Callovian to Lower Cretaceous pelagic carbonates in the West Balkan Mountains (Komshtitsa and Barlya sections): integrated biostratigraphy and microfacies. Geologica Balcanica 36 (3-4), 81-89.

Le Hégarat, G. 1973. Le Berriasien du Sud-Est de la France. Documents des Laboratoires de Géologie de la faculté des sciences de Lyon 43 (1-2), 1-576.

Lukeneder, A. 2012. New biostratigraphic data on an Upper Hauterivian-Upper Barremian ammonite assemblage from the Dolomites (Southern Alps, Italy). Cretaceous Research $35,1-21$.

Lukeneder, A. 2016. A Late Valanginian Mediterranean ammonoid fauna from the Lunz Nappe (Northern Calcareous Alps; Lower Austria). Austrian Journal of Earth Sciences 109 (2), 252-261.

Mandov, G. 1971. Représentants du genre Bochianites Lory, 1898 (Ammonoidea) dans les dépôts du Crétacé inférieur en Bulgarie. Bulletin of the Geological Institute, Series Paleontology 20, 91-106 (in Bulgarian, with Russian and French abstracts).

Mandov, G. 1975. On the occurrence of straight ammonites in the Berriasian stage in the Eastern Fore-Balkan. Palaeontology, Stratigraphy and Lithology 1, 47-52 (in Bulgarian, with Russian, English and French abstracts).

Mandov, G. 1976. L'étage Hauterivien dans les Balkanides occidentales (Bulgarie de l'ouest) et sa faune d'ammonites. Annuaire de l'Université de Sofia, Faculté de Géologie et Géographie 67 (1), 11-99 (in Bulgarian, with French summary).

Mandov, G. 1990. Sur la présence des couches avec Thurmanniceras otopeta Thieuloy, 1979 dans le Valanginien inférieur du Prébalkan Central (Bulgarie du nord). Comptes rendus de l'Académie bulgare des Sciences 43 (3), 59-61.

Mazenot, G. 1939. Les Palaeohoplitidae tithoniques et berriasiens du sud-est de la France. Mémoires de la Société Géologique de France (nouvelle série) 18, Mémoire 41, $1-303$.
Mihailova-Yovcheva, P., Trifonova, E. 1967. Microfaunistic data on the stratigraphy of the Upper Jurassic, Berriasian and Valanginian in drillings from N.E. Bulgaria. Review of the Bulgarian Geological Society 28 (2), 153-174 (in Bulgarian, with English abstract).

Nikolov, T. 1960. La faune d'ammonites dans le Valanginien du Prébalkan Oriental. Travaux sur la géologie de Bulgarie, Série Paléontologie 2, 143-264 (in Bulgarian, with Russian and French abstracts).

Nikolov, T. 1962. Stratigraphy of the Lower Cretaceous in the Fore-Balkan, East of the Brestova River. Bulletin of the Geological Institute, Series Paleontology 11, 185-202 (in Bulgarian, with Russian and English abstracts).

Nikolov, T. 1966. New genera and subgenera of ammonites of the family Berriasellidae. Comptes rendus de l'Académie bulgare des Sciences 19 (7), 639-642.

Nikolov, T. 1982. Les ammonites de la famille Berriasellidae Spath, 1922. Tithonique supérieur-Berriasien. Editions de l’Académie bulgare des sciences, Sofia, 251 pp.

Nikolov, T., Ruskova, N., Krischev, K. 1991. Principles of the Lower Cretaceous lithostratigraphy in Bulgaria. Geologica Balcanica 21 (6), 3-47 (in Russian, with English abstract).

Olszewska, B. 2010. Microfossils of the Upper Jurassic-Lower Cretaceous formations of the Lublin Upland (SE Poland) based on thin section studies. Polish Geological Institute Special Papers 26, 1-56.

Petrova, S. 2011. Ammonite and calpionellid biostratigraphy of the Berriasian, Valanginian and Hauterivian stages in the Western Srednogorie and the Western Balkan Mountains. $\mathrm{PhD}$ thesis, Bulgarian Academy of Sciences, Geological Institute "Str. Dimitrov", 353 pp. (in Bulgarian).

Petrova, S., Koleva-Rekalova, E., Ivanova, D., Lakova, I. 2019. Biostratigraphy and microfacies of the pelagic carbonate formations in the Yavorets section (Tithonian-Berriasian), Western Balkan Mts, Bulgaria. Geologica Balcanica 48 (2), 51-73.

Petrova, S., Metodiev, L. 2012. Berriasian and Valanginian calpionellids from the Ticha Formation of the East ForeBalkan (Bulgaria). Bulgarian Geological Society, National Conference with International Participation "Geosciences 2012", 95-96.

Petrova, S., Rabrenović, D., Lakova, I., Koleva-Rekalova, E., Ivanova, D., Metodiev, L., Malešević, N. 2012. Biostratigraphy and microfacies of the pelagic carbonates across the Jurassic/Cretaceous boundary in eastern Serbia (Stara Planina-Poreč Zone). Geologica Balcanica 41 (1-3), 53-76.

Pop, G. 1994a. Systematic revision and biochronology of some Berriasian-Valanginian calpionellids (genus Remaniella). Geologica Carpathica 45 (6), 323-331.

Pop, G. 1994b. Calpionellid evolutive events and their use in biostratigraphy. Romanian Journal of Stratigraphy 76, 7-24.

Pop, G. 1997a. Révision systématique des chitinoïdelles Tithoniennes des Carpathes méridionales (Roumanie). Comptes rendus de l'Académie des Sciences de Paris, Série IIa 324, 931-938.

Pop, G. 1997b. Tithonian to Hauterivian praecalpionellids and calpionellids: bioevents and biozones. Mineralia Slovaca 29 (4-5), 304-305.

Pszczółkowski, A., Myczyński, R. 2004. Ammonite-supported microfossil and nannoconid stratigraphy of the TithonianHauterivian limestones in selected sections of the Branisko Succession, Pieniny Klippen Belt (Poland). Studia Geologica Polonica 123, 133-197.

Reboulet, S. 1996. L'évolution des ammonites du Valanginien-Hauterivien inférieur du bassin vocontien et de la plate-forme provençale (Sud-Est de la France): relations avec la stratigraphie séquentielle et implications bio- 
stratigraphiques. Documents des Laboratoires de Géologie de Lyon 137 (1995), 1-371 (in French, with English abstract).

Reboulet, S., Szives, O., Aguirre-Urreta, B., Barragán, R., Company, M., Frau, C., Kakabadze, M.V., Klein, J., Moreno-Bedmar, J.A., Lukeneder, A., Pictet, A., Ploch, I., Raisossadat, S.N., Vašíček, Z., Baraboshkin, E.J., Mitta, V.V. 2018. Report of the $6^{\text {th }}$ International Meeting of the IUGS Lower Cretaceous Ammonite Working Group, the Kilian Group (Vienna, Austria, $20^{\text {th }}$ August 2017). Cretaceous Research 91, 100-110.

Reháková, D. 2000. Evolution and distribution of the Late Jurassic and Early Cretaceous calcareous dinoflagellates recorded in the Western Carpathian pelagic carbonate facies. Mineralia Slovaca 32 (2), 79-88.

Reháková, D., Michalík J. 1997. Evolution and distribution of calpionellids - the most characteristic constituents of Lower Cretaceous Tethyan microplankton. Cretaceous Research 18, 493-504.

Remane, J. 1963. Les calpionelles dans les couches de passage Jurassique-Crétacé de la fosse vocontienne. Travaux du Laboratoire de Géologie, Grenoble 39, 25-82.

Remane, J. 1965. Neubearbeitung der gattung Calpionellopsis Col. 1948 (Protozoa, Tintinnina?). Neues Jahrbuch für Geologie und Paläontologie Abhandlungen 122 (1), 27-49.

Sapunov, I. 1976. Ammonite stratigraphy of the Upper Jurassic in Bulgaria. I. Rock and ammonite successions. Geologica Balcanica 6 (3), 17-40.

Sapunov, I., Tchoumatchenco, P., Baburkov, I., Bakalova, D., Dodekova, L., Zheleva, T., Nikolova, M., Černjavska, S. 1986. The Jurassic System from the new subsurface sections in the area of Provadija. Review of the Bulgarian Geological Society 47 (2), 103-120 (in Bulgarian, with English abstract).
Sarasin, C., Schöndelmayer, C. 1902. Étude monographique des ammonites du Crétacique inférieur de Chatel-SaintDenis. Mémoires de la Société Paléontologique Suisse 29, 95-195.

Tavera, J.M. 1985. Los ammonites del Tithónico superior-Berriasense de la zona Subbética (Cordilleras Béticas). $\mathrm{PhD}$ thesis, University of Granada. 381 pp. (in Spanish)

Vangelov, D., Sinnyovsky, D. 2007. Stratigraphy of the Upper Cretaceous and Paleogene in a part of the Eastern Forebalkan between the rivers Luda Kamchiya and Armera. Annuaire de l'Université de Sofia, Faculté de Géologie et Géographie 1 (99), 31-51 (in Bulgarian, with English abstract).

Vašíček, Z. 1999. Comments on some new occurrences of heteromorph ammonites in the Lower Cretaceous (late Valanginian - early Barremian) of the Eastern Alpine and Western Carpathian systems. Scripta Geologica, Special Issue 3, 215-227.

Vašíček, Z. 2020. Early Cretaceous ammonites of the superfamily Bochianitoidea from the Butkov Quarry (Central Western Carpathians, Slovakia). Neues Jahrbuch für Geologie und Paläontologie 298 (1), 75-85.

Vašíček, Z., Reháková, D., Faupl, P. 1999. Zur Biostratigraphie der Schrambachschichten der Oisbergmulde bei Hollenstein a.d. Ybbs (Lunzer Decke, Kalkalpen, Niederösterreich). Abhandlungen der Geologischen Bundesanstalt 56 (2), 625-650.

Vermeulen, J. 2006. Nouvelle classification à fondement phylogénétique des ammonites hétéromorphes du Crétacé inférieur. Annales du Muséum d'Histoire Naturelle Nice 21, 137-178.

Wierzbowski, A., Remane, J. 1992. The ammonite and calpionellid stratigraphy of the Berriasian and lowermost Valanginian in the Pieniny Klippen Belt (Carpathians, Poland). Eclogae Geologicae Helvetiae 85 (3), 871-891. 